\title{
Problem-Based Learning To Improve Concept Understanding and Critical Thinking Ability of Science Education Undergraduate Students
}

\author{
Mellyta Uliyandari ${ }^{1}$, Emilia Candrawati ${ }^{2}$, Anna Ayu Herawati ${ }^{3}$, Nurlia Latipah ${ }^{3}$ \\ 1,2,3 Universitas Bengkulu, Bengkulu, Indonesia \\ ${ }^{4}$ Institut Agama Islam Negeri Bengkulu, Bengkulu, Indonesia
}

\begin{tabular}{|c|c|}
\hline (A) Check for updates open access cc) (i) (2) & DOI : https://doi.org/10.46245/ijorer.v2i1.56 \\
\hline Sections Info & ABSTRACT \\
\hline $\begin{array}{l}\text { Article history: } \\
\text { Submitted: Augustus 11, } 2020 \\
\text { Final Revised: January 11, } 2021 \\
\text { Accepted: January, } 142021 \\
\text { Published Online: January 31, } 2021\end{array}$ & $\begin{array}{l}\text { This reserach was conducted to improve conceptual understanding and } \\
\text { critical thinking ability of fourth-semester students of the Science } \\
\text { education study program, Bengkulu University by applying PBL. The } \\
\text { research method used in this study is quasi experimental, which in its } \\
\text { implementation uses single class or one group pretest-posttest design. }\end{array}$ \\
\hline $\begin{array}{l}\text { Keywords: } \\
\text { Concept Understanding } \\
\text { Learning model } \\
\text { Problem Based Learning (PBL) } \\
\text { Think critically }\end{array}$ & $\begin{array}{l}\text { The test question was the instrument used in this study. The findings } \\
\text { showed that there was an improvement in students conceptual } \\
\text { understanding and critical thinking ability of students since } \\
\text { implementing problem-based learning models in environmental } \\
\text { chemistry courses. This improvement can be seen from the results of the } \\
\text { gain test for each class group on the test of conceptual understanding }\end{array}$ \\
\hline 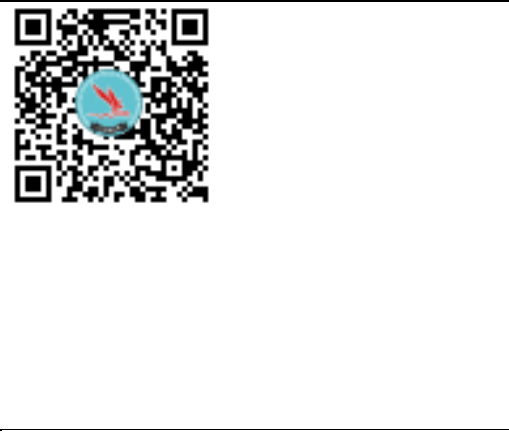 & $\begin{array}{l}\text { and critical thinking ability which are in the "medium" category, while } \\
\text { the t-test results for concept understanding and critical thinking ability } \\
\text { show a significant difference }(0.000<0.05) \text {. In other words, the } \\
\text { implementation of the PBL learning influences the students' conceptual } \\
\text { understanding and critical thinking ability. Further the implementation } \\
\text { of the problem-based learning model in teaching and learning process } \\
\text { presents problems with real conditions so that it can stimulate students to } \\
\text { not only think and understand at the rote level but also interpret the } \\
\text { problem. Quiet in-depth research on the implementation of problem- } \\
\text { based learning models in learning is highly recommended to get more } \\
\text { comprehensive results. }\end{array}$ \\
\hline
\end{tabular}

\section{INTRODUCTION}

Education in Indonesia is an important part of efforts to educate the nation's life and improve the quality of human resources (Siregar et al., 2016). Education is still an effort to change the mindset so that humans can solve various problems (Schroder et al., 2017). The world of education has experienced rapid development, information and communication are always developing all the time. These Conditions have created a tight competition in the world of education, so it requires quality professional educators to deal with it (Zalia \& Lasmawan, 2013).

Education in the current global era requires not only mastery and understanding of the material but still requires students to have cognitive and social abilities to solve existing problems (Haryanti, 2017). Learning that is on target and can achieve educational goals can improve the quality of learning (Dirgatama et al., 2016). A good understanding of the concepts of each student must go with the optimal learning process regarding the material being taught. An important thing is the concept of learning, but it does not lie in the concept itself, but in how students understand the concept. 
Problem-Based Learning To Improve Concept Understanding and Critical Thinking Ability of Science Education Undergraduate Students

Understanding concepts in the teaching and learning process affects student behaviors, choices, and how to solve challenges for the present and the future (Kuning, 2012). Understanding concepts play an important role in learning and the problemsolving process, both in the learning environment and in everyday life (Hamzah, 2016). Indicators of conceptual comprehension are as follows: Restate a definition; (2) Identify objects according to particular characteristics (according to the concept); (3) Provide an example and not an example of a concept; (4) Present the concept in different types of mathematical representation; (5) Establish the required or appropriate conditions of a concept; (6) Use and selection of specific processes or operations; (7) Apply concepts or problem-solving methods (Yulianti \& Indra, 2019).

Students' critical thinking ability must support an optimal understanding of the concept. According to Ulger (2018), the ability to think critically must be improved, especially in an era that is increasingly developing and digitizing as it is today. We may describe critical thinking as someone's attempt to verify the truth of knowledg e using the availability of proof, logic, and awareness of bias (Larsson, 2017). Critical thinking is a technique in making rational decisions (Purwati et al., 2016).

Thinking ability are grouped into two, namely primary thinking ability and complex or high-level thinking ability. Here, primary thinking ability have connecting cause and effect, transforming, finding relationships, and providing facilities, or in the other word primary thinking ability is a process of higher-order (Rahayu et al., 2017). The indicators of critical thinking include (1) Simple explanation, (2) primary ability development, (3) inferences, (4) clarify, (5) strategies and tactics. Although conceptual understanding of learning materials and the ability to think critically are very important things in the learning process, in fact not all students have high critical thinking ability, as happened in the S1 Science Education study program. Based on the observations, we know that students are passive when taking part in classroom learning activities. When delivering material by the lecturer, or during the question-and-answer session, only a few students will ask or respond to questions given by the lecturer.

The learning quality can be develop by improving the teacher, lecture, or instructor ability to transfer the learning materials and the quality of teaching and learning process itself will be increased automatically (Kono et al., 2016., Safaruddin, Ibrahim, et al., 2020). The choice of the right learning model can help lecturers in delivering learning material, so it is understood by students. The learning model is a collection of structured presentations of teaching materials, including aspects before, during, and after the teacher's learning process, and all associated facilities used directly or indirectly in the learning process (Uliyandari \& Elly, 2020). Another study that in line with the results of this study written by Yohana et al. (2018) the use of PBL in Universitas Negeri Surabaya psychology students improves the students' critical thinking.

The PBL model is a model focused on a particular topic (Bakhri \& Supriadi, 2017). This model aims to study content, process ability, problem-solving, and study issues in the actual world. (Khoiriyah \& Husamah, 2018). The implementation of this model designed in order to encourage students to become researcher, analytical, and innovative (Kassab et al., 2017). so, the PBL model can help encourage students to think and work rather than just memorizing and telling stories (Trianto, 2010). According to Masek \& Yamin (2011), the PBL learning model can also increase student motivation to 
learn by solving problems. PBL also allows students to be involved in the discussion activities (Asyari et al., 2016., Safaruddin, Degeng, et al., 2020).

PBL was a pedagogical approach developed in medical schools. The problems in the PBL approach become a stimulus for students in learning activities. While learning, we aim at finding solutions to problems (Orozco \& Yangco, 2016). According to Synder and Wiles (2015), critical thinking ability can be developed with student-centered teaching methods such as PBL. According to J. Oja (2011), The application of PBL to student critical thinking ability has a positive relation. However, it must be tightened to assess critical thinking with PBL. Based on the description above, the researcher tried to use PBL model to fourth-semester students' of Science Education program at the University of Bengkulu to improve their conceptual understanding and critical thinking ability.

\section{RESEARCH METHOD}

\section{General Background}

This research provides treatment and measures the effects of treatment also known as quasi-experiment (pseudo-experiment). This research uses one group pretest-posttest and this research does not use a random sample to determine the changes caused by the treatment (Sugiyono, 2010).

\section{Sample / Participants/ Group}

The sample were 27 semester IV class B students of the Science Education Program, Teacher Training and Education Faculty of University Bengkulu.

\section{Instrument and Procedures}

The test is an instrument in this study to measure the conceptual understanding and critical thinking ability of students', the test was carried out in the pretest and posttest session. Indicators used to determine students' conceptual understanding are, when students can interpret (interpretation), exemplify, classify, summarize, conclude (inference), compare, explain according to the concept. Students' understanding of the concept can be seen from the score or value that shows the understanding of the concept, especially in water pollution material, and got through giving tests at the end of the learning process. Constructing knowledge requires critical thinking ability competencies. The indicators of critical thinking ability are, (a) analysis ability, (b) synthesis ability, (c) recognition and problem-solving ability, (d) conclusion ability, (e) evaluation ability or judge (Istiqamah, 2019).

\section{Data Analysis}

Data analysis was performed using independent sample t-test. which is done with the SPSS 16.0. The test is carried out at a significant level of $5 \%$, meaning that to determine the $t$-table statistical value, the significant level is used $\alpha=0.05$ with degrees of freedom $\mathrm{dk}=(\mathrm{nk}-1)$, with the testing criteria accepted Ho If $\mathrm{t}<\mathrm{t}_{\mathrm{table}}$, and accepted Ha if $\mathrm{t}_{\text {count }} \geq$

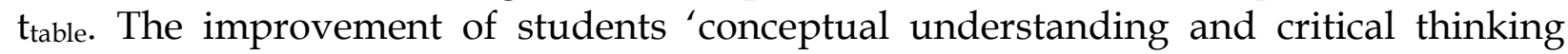
determined by calculating the difference of students' scores between the pretest and post test scores after the implemetation problem-based learning (PBL) model. To calculate the difference between pretest and posttest scores, gain score or N-gain is the 
Problem-Based Learning To Improve Concept Understanding and Critical Thinking Ability of Science Education Undergraduate Students

researcher used the Hake (in Yulianti \& Indra, 2019) formula and classification of gain values.

$$
\mathrm{N}_{\text {-gain }}=\frac{s_{\text {Post }} s_{\text {Pre }}}{s_{\max }-s_{\text {Pre }}}
$$

Table 1. N-gain value classification.

\begin{tabular}{cc}
\hline Gain Value & Interpretation \\
\hline $\mathrm{g}>0,7$ & High \\
$0,7>\mathrm{g}>0,3$ & Medium \\
$\mathrm{g}<0,3$ & Low \\
\hline
\end{tabular}

\section{RESULTS AND DISCUSSION}

Data analysis of students' conceptual understanding and critical thinking from students' pretest and posttest scores analyzed with n-gain test (Yulianti \& Indra, 2019). The results of the average pretest and posttest scores of students and $\mathrm{N}$ gain score for conceptual understanding and critical thinking ability of students shown in Figure 1, Table 2 and Table 3.

The average value of students' pretest and posttest in understanding concepts and critical thinking abilities

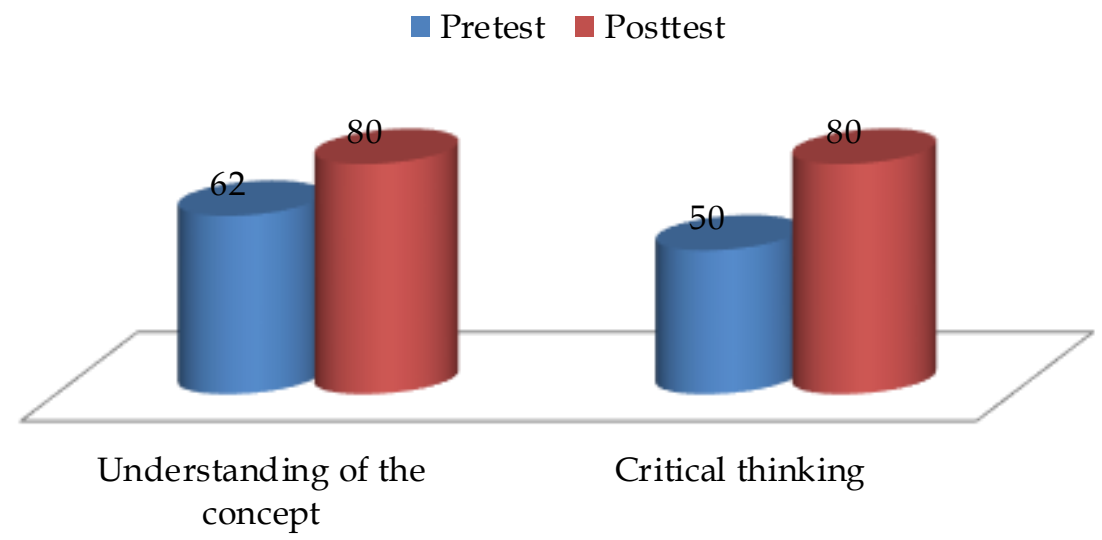

Figure 1. Graph of students' average pretest and posttest scores on conceptual understanding and critical thinking ability.

Table 2. Score Gain for each group of students on the concept understanding test.

\begin{tabular}{|c|c|c|c|c|}
\hline Group & Frequency & $\mathbf{N}_{\text {-gain }}$ & Criteria & Significant \\
\hline High & 4 & 0,56 & Moderate & $\begin{array}{c}\mathrm{t} \text { count }>\mathrm{t} \text { table } \\
23,519>1,706\end{array}$ \\
\hline Moderate & 18 & 0,46 & Moderate & $\begin{array}{c}\text { Sig (2-tailed) } \\
0,000<0,05\end{array}$ \\
\hline Low & 5 & 0,47 & Moderate & Real different \\
\hline
\end{tabular}


Problem-Based Learning To Improve Concept Understanding and Critical Thinking Ability of Science Education Undergraduate Students

Table 3. Score Gain of each group of students on the critical thinking ability test.

\begin{tabular}{|c|c|c|c|c|}
\hline Group & Frequency & $\mathbf{N}_{\text {-gain }}$ & Criteria & Significant \\
\hline High & 4 & 0,68 & Moderate & $\begin{array}{c}\mathrm{t} \text { count }>\mathrm{t} \text { table } \\
34,706>1,706\end{array}$ \\
\hline Moderate & 18 & 0,59 & Moderate & $\begin{array}{c}\text { Sig (2-tailed) } \\
0,000<0,05\end{array}$ \\
\hline Low & 5 & 0,57 & Moderate & Real different \\
\hline
\end{tabular}

Based on Figure 1 the students' average scores of pretest and posttest on the conceptual understanding test were 63 and 80, and the students' pretest and posttest average scores for critical thinking ability test were 50 and 80 . The results show that there are differences scores between students' pretest and posttest scores, to determine the improvement in students' conceptual understanding and critical thinking ability from students' pretest, and posttest scores were calculated using the gain test as shown in tables 2 and 3 . Based on tables 2 and 3 it is known that the results of the gain test in each class group for conceptual understanding in the high, medium, and low classes were 0.68 ; 0.69; and 0.57 in the "medium" category. Students' critical thinking ability also have an improvement which show from the N-gain score of each group, where the N-gain score for high, medium, and low classes is $0.68,0.59$, and 0.57 which are in the "medium" category while the significance value is $0.000<0.05$ (significantly different). The results of $t$-test of show a significant difference, it means that there was an effect implementation PBL model on students' conceptual understanding and critical thinking ability. This is in line with Kono's research (2016) that the PBL model improve conceptual understanding and critical thinking ability of class X SMA Negeri 1 Sigi.

The improvement score of students' after the PBL model implementation because this model positioned students as self-directed learners so that students have a bigger role than lecturers in terms of the occurrence of knowledge construction in students. The PBL model also based on authentic problems (Bakri \& Supriadi, 2017) the PBL model purpose to study content, process skills, problem-solving, and also study problems in the real world (Khoriyah \& Husamah) 2018). Further, the implementation of PBL model learning kodel presents problems with real conditions so that it can stimulate students not only to think and understand at the rote level but also to interpret the problem.

Furthermore, fourth-semester students who were entering the late adolescent phase were was a critical or transition period for the development of thinking ability (cognitive). In line with the result of Wynn Sr et al. (2014) where the characteristics of student cognitive development are suitable if given a learning model that stimulates a thinking model with problems, cases, and problem-solving discussions as contained in the PBL model. In this PBL model, the lecturer acts as a facilitator to provide students with the environment tobe more active in learning process. Wynn Sr et al. (2014) explained that the learning environment in the PBL model the students more active because PBL required students to be active both in thinking and expressing the results of their thoughts so that student involvement and collaboration are also high. 
Problem-Based Learning To Improve Concept Understanding and Critical Thinking Ability of Science Education Undergraduate Students

\section{CONCLUSIONS}

The results and discussion show that the implementation of PBL model in environmental chemistry subjects of science education program can improve students' conceptual understanding and critical thinking ability. The results shows an improvement from the pretest and posttest averages scores, which were analyzed by $\mathrm{t}-$ test. and also from the results of the $\mathrm{N}$-gain score. The $\mathrm{N}$-gain result show the improvement in each group. So there is an effect on the PBL model implementation on students' conceptual understanding and critical thinking ability. Therefore, the PBL model can be recommended to be applied by the lecture. More in-depth research on the application of PBL model is highly recommended to get more comprehensive results.

\section{REFERENCES}

Asyari, M., Al Muhdhar, M. H., \& Ibrohim, H. S. (2016). improving critical thinking ability through the integration of problem based learning and group investigation. International Journal for Lesson and Learning Studies, 5(1), 36-44. http://dx.dio.org/10.1108/IJLLS-10-2014-0042

Bakhri, Syaifulloh \& Supriadi. 2011. Peran problem-based learning (PBL) dalam upaya peningkatan higher order thinking skills (HOTs) siswa pada pembelajaran matematika. Seminar Matematika dan Pendidikan Matematika Uny 2017. Isbn. 978602-73403-2-9 (Print) 978-602-73403-3-6 (On-Line)

Dirgatama, C. H. A.., Santoso, T D., \& Ninghardjanti, P. (2016). Penerapan model pembelajaran problem based learning dengan mengimplementasi program microsoft excel untuk meningkatkan keaktifan dan hasil belajar mata pelajaran administrasi kepegawaian di SMK Negeri 1 Surakarta. Jurnal Informasi Dan Komunikasi Administrasi Perkantoran, 1(1), 36-53.

Hamzah, B. U (2016). Perencanaan pembelajaran. Jakarta: Bumi aksara.

Haryanti, Y. D. (2017). Model problem based learning membangun kemampuan berpikir kritis siswa sekolah dasar. Jurnal Cakrawala Pendas, 3(2), 57-63. http://dx.doi.org/10.31949/jcp.v3i2.596

Istiqamah. (2019). Perbandingan pemahaman dan kemampuan berpikir kritis melalui model pembelajaran discovery learning dan direct instruction. Chemistry education Review, 3(1), 17-30. DOI: https:// doi.org/10.26858/cer.v2i2.8671

J. Oja, K. (2011). Using problem-based learning in the clinical setting to improve nursing students' critical thinking: An evidence review. Journal of Nursing Education, 50(3), 145-151. https://doi.org/10.3928/01484834-20101230-10

Kassab, S. E., Hassan, N., El-araby, S., Salim, A. H., Alrebish, S. A., Al-amro, A. S., \& Hamdy, H. (2017). Development and validation of the motivation for tutoring questionnaire in problem-based learning programs. Health Professions Education, 3(1), 50-58. https://doi.org/10.1016/j.hpe.2017.03.001

Khoiriyah, Anna Jarrotul. \& Husamah. 2018. Problem-based learning: Creative thinking ability, problem-solving ability, and learning outcome of seventh grade students. JPBI (Jurnal Pendidikan Biologi Indonesia), 4(2), 151-160. https://doi.org/10.22219/jpbi.v4i2.5804

Kono, R., Hartono D. M., \& Lilies, N. T. (2016). Pengaruh Model Problem Based Learning (PBL) Terhadap Pemahaman Konsep Biologi dan Keterampilan Berfikir 
Problem-Based Learning To Improve Concept Understanding and Critical Thinking Ability of Science Education Undergraduate Students

Kritis Siswa Tentang Ekosistem dan Lingkungan di Kelas X SMA Negeri 1 Sigi. Jurnal Sains dan Teknologi Tadulako, 5(1), 28-38.

Kuning, D. P. R. (2012). Strategi pembelajaran berbasis masalah untuk meningkatkan kemampuan berfikir kritis siswa. Jurnal Ilmiah Guru, 16(2), 26-35.

Larsson, K. (2017). Understanding and teaching critical thinking-A new approach. International Journal of Educational Research, 8(4), 32-42. http://doi.org/10.1016/j.ijer.2017.05.004

Masek \& Yamin, S. (2011). The effect of problem based learning on critical thinking ability: A theoretical and empirical review. International Review of Social Sciences and Humanities, 2(1), 215-221. http://doi.org/10.1109/CHUSER.2011.6163841

Orozco, J. A., \& Yangco, R. T. (2016). Problem-based learning: Effects on critical and creative thinking ability in biology. Asian Journal of Biology Education, 9(3), 2-10

Purwati, Ratna., Hobri., \& Arif Fatahillah. (2016). Analisis kemampuan berfikir kritis siswa dalam menyelesaikan masalah persamaan kuadrat pada pembelajaran model creative problem solving. Jurnal Kadikma, 7(1), 84-93.

Rahayu, S., Johanes, S., \& Alxson. (2017). Penerapan model problem based learning (PBL) untuk meningkatkan keterampilan berfikir kritis dan prestasi belajar siswa (Studi pada mata pelajaran IPA kelas V pada SDN Gugus II Raflesia Talang Empat Kabupaten Bengkulu Tengah). Jurnal Ilmiah Teknologi Pendidikan, 7(2), 98-110.

Safaruddin, Degeng, I. N. S., Setyosari, P., \& Murtadho, N. (2020). The effect of PJBL with WBL media and cognitive style on students' understanding and scienceintegrated concept application. Jurnal Pendidikan IPA Indonesia, 9(3), 384-395. https://doi.org/10.15294/jpii.v9i3.24628

Safaruddin, S., Ibrahim, N., Juhaeni, J., Harmilawati, H., \& Qadrianti, L. (2020). The Effect of Project-Based Learning Assisted by Electronic Media on Learning Motivation and Science Process Skills. Journal of Innovation in Educational and Cultural Research, 1(1), 22-29. https:// doi.org/10.46843/jiecr.v1i1.5

Schroder, H. Fisher, M. E. Lin, Y. Lo, S. L. Danovitch, J. H. \& Moser, J. S. (2017). Neural evidence for enhanced attention to mistake among school-aged children with growth mindset. Developmental Cognitive Neuroscience, 24(1), 42-50. https://doi.org/10.1016/j.dcn.2017.01.004

Siregar, Purwanto, \& Seri. (2016). Pengaruh model pembelajaran problem based learning (PBL) terhadap belajar siswa pada materi pokok suhu dan kalor di kelas X semester II sma negeri 11 medan t.p 2014/2015. Jurnal Ikatan Alumni Fisika Universitas Negeri Malang, 2(1),26. https:// doi.org/10.24114/jiaf.v2i1.3736

Snyder, J. J., \& Wiles, J. R. (2015). Peer led team learning in introductory biology: Effects on peer leader critical thinking ability. Plos ONE, 10(1), 1-18. https://doi.org/10.1371/journal.pone.0115084

Sugiyono. (2010). Metode penelitian pendidikan pendekatan kuantitatif, kualitatif, dan RED. Bandung: Alfabeta

Trianto. (2010). Model pembelajaran terpadu, konsep, strategi dan implementasinya dalam KTSP. Jakarta: Bumi Aksara.

Uliyandari, Mellyta \& Elly Effrida Lubis. (2020). Penerapan Model Pembelajaran Inkuiri dengan Media alat peraga (Gunung Berapi) Pada Mata Pelajaran IPA SDN 013 Bengkulu Utara. PENDIPA Journal of Science Education, 4(2), 74-78. https://doi.org/10.33369/pendipa.4.2.74-78 
Problem-Based Learning To Improve Concept Understanding and Critical Thinking Ability of Science Education Undergraduate Students

Ulger, Kani. (2018). The Effect of Problem-Based Learning on the Creative Thinking and Critical Thinking Disposition of Students in Visual Arts Education. Interdisciplinary Journal of Problem-Based Learning, 12(1). : https://doi.org/10.7771/1541-5015.1649

Wynn Sr, C. T., Mosholder, R. S., \& Larsen, C. A. (2014). Measuring the effects of problem-based learning on the development of postformal thinking ability and engagement of first-year learning community students. Learning Communities: Research \& Practice, 2(2),1-23.

Yohana, Wuri Satwika., Hermien Laksmiwati., \& Riza Noviana Khoirunnisa. (2018). Penerapan model problem based learning untuk meningkatkan kemampuan berfikir kritis mahasiswa. Jurnal Pendidikan (Teori dan Praktik), 3(1), 7-12. DOI: http://dx.doi.org/10.26740/ip.v3n1.p7-12

Yulianti, E., \& Indra, G. (2019). Model pembelajaran problem based learning (PBL) : Efeknya terhadap pemahaman konsep dan berfikir kritis. Indonesia Journal of Science and Mathematics Education, 2(3), 399-408.

https://doi.org/10.24042/ijsme.v2i3.4366

Zalia muspita, i. w. lasmawan, dan s. (2013). Pengaruh model pembelajaran berbasis masalah terhadap kemampuan berfikir kritis, motivasi belajar, dan hasil belajar IPS siswa kelas VII SMPN 1 Aikmel. Journal Program Pascasarjana Universitas Pendidikan Ganesha Program Studi Pendidikan Dasar, 3(1), 1-8.

*Mellyta Uliyandari, M.Pd.Si. (Corresponding Author)

Science Education Study Program, Universitas Bengkulu

WR Supratman St, Kandang Limun. Bengkulu, 38123, Indonesia

Email: mellytauliyandari@unib.ac.id

Emilia Candrawati, M.Pd.

Science Education Study Program, Universitas Bengkulu

WR Supratman St, Kandang Limun. Bengkulu, 38123, Indonesia

Email: emiliacandrawati@unib.ac.id

Anna Ayu Herawati, M.Pd.

Guidance and counseling Study Program, Faculty of Education, Universitas Bengkulu

WR Supratman St, Kandang Limun. Bengkulu, 38123, Indonesia

Email: annaayuherawati@unib.ac.id

Nurlia Latipah, M.Pd.

Science Tadris Study IAIN Bengkulu

Raden Patah St, Pagar Dewa. Bengkulu, 65144, Indonesia

Email : nurlialatipah@iainbengkulu.ac.id 